\title{
Kesantunan dalam Ritual Pernikahan Masyarakat Hindu-Bali; Kajian Etnopsikolingustik Religius
}

\author{
Kadek Devi Kalfika Anggria Wardani \\ Universitas Pendidikan Nasional (Undiknas) Denpasar
}

\section{Keywords:}

politeness strategies;

culture ;

balinese Marriage;

psychology

\section{Kata kunci:}

strategi kesantunan; budaya;

pernikahan adat Bali; psikologi;

\begin{abstract}
Abstract: The study which is descriptive qualitative in nature, aims to investigate preference of politeness strategies by Balinese Hindu-community in traditional marriage ritual. Data was collected using interview and observation methods. Based on the results of data analysis, this research shows that the form of politeness that arises can be seen in terms of place, time, to the leaders of the people, during preparation, implementation, disclosure of the relationship with the Almighty, and after the completion of the ritual. The different forms of politeness that emerge can be seen from the use of Balinese in various levels which are adjusted to the social distance and speech situation. Besides being seen from the use of language, linguistic politeness is also evident from the attitude, intonation, and tone of the speaker. The difference in the form of politeness is intentionally raised to cause certain psychological impacts on the interlocutor.
\end{abstract}

\begin{abstract}
Abstrak: Studi ini merupakan sebuah studi kulitatif yang mendeksripsikan mengenai bentuk-bentuk kesatunan dalam ritual pernikahan masyarakat Hindu di Bali. Data dikumpulkan dengan mengggunakan metode wawancara dan observasi. Berdasarkan hasil analisis data, penelitian ini menunjukkan bahwa bentuk kesatunan yang muncul dapat dilihat dari segi tempat, waktu, kepada tokoh umat, saat persiapan, pelaksanaan, pengungkapan hubungan dengan Yang Maha Kuasa, dan setelah selesai ritual. Perbedaan bentuk kesantunan yang muncul tersebut dapat dilihat dari penggunaan bahasa Bali dalam berbagai tingkatan yang disesuaikan dengan jarak sosial dan situasi tuturan. Selain terlihat dari penggunaan bahasa, kesantunan linguistik juga tampak dari sikap, intonasi, dan nada penutur. Perbedaan bentuk kesantunan tersebut secara sengaja dimunculkan untuk menimbulkan dampak psikologi tertentu kepada lawan tutur.
\end{abstract}

\footnotetext{
Alamat Korespondensi:

E-mail: devikalfika@undiknas.ac.id (Kadek Devi Kalfika Anggria Wardani)
}

\section{Pendahuluan}

Kesantunan merupakan salah satu konsep penting dalam interaksi sehari-hari dan menjadi bagian integral dalam sebuah interaksi sosial. Konsep ini dalam beberapa dekade terakhir telah mengundang ketertarikan banyak peneliti dan tidak hanya menjadi fokus kajian pragmatik, tetapi juga displin ilmu lain seperti psikolinguistik (Isosävi, 2020; Lakoff, 2005; Nurilaila \& Madiun, 2020). Salah satu faktor yang menyebabkan mengapa kesantunan dianggap sebagai sebuah isu penting, karena banyak kalangan menilai bahwa keberhasilan sebuah interaksi sosial di antara manusia bergantung pada seberapa besar kehendak penutur untuk bekerja sama dalam melakukan interaksi 
sosial sesuai dengan aturan kebudayaan setempat untuk mencegah bentuk-bentuk interaksi sosial tertentu yang tidak diinginkan, seperti konfrontatif dan kompetitif (Lakoff dan Ide, 2005).

Para peneliti telah menemukan bahwa semua kebudayaan memiliki seperangkat perilaku dan sikap yang dikategorikan sebagai sebuah "kesantunan". Manifestasi perilaku kesantunan dari anggota masyarakat yang memiliki kebudayaan berbeda, diperkirakan berada dalam keadaan yang serupa, yaitu secara umum menyangkut kapan, bagaimana, dan kepada siapa (Yule, George, 2017). Dengan kata lain meskipun manifestasi perilaku kesantunan berbeda antara satu kebudayan dengan kebudayan yang lain, terdapat kesamaan prinsip yang melandasi perilaku kesantunan tersebut, yaitu kapan perilaku tersebut dilakukan, bagaimana perilaku santun ditunjukkan, dan kepada siapa perilaku santun tersebut ditunjukkan (Spencer-oatey \& Kádár, 2016).

Adanya manifestasi kesantunan yang berbeda antara satu kebudayaan dengan kebudayaan yang lain, seringkali menimbulkan bentuk interaksi sosial yang negatif, seperti konflik. Hal ini disebabkan karena kurang atau tidak adanya pehamanan konsep "kesantunan" (Lakoff dan Ide, 2005:27). Oleh karena itu, diperlukan adanya pemahaman terhadap konsep kesantunan yang berlaku dalam budaya mitra tutur, untuk menciptakan sebuah komunikasi yang efektif. Terlebih, seiring dengan pertumbuhan dunia yang semakin mengglobal, isu mengenai kesantunan berbahasa semakin penting untuk dikedepankan. Hal ini terkait dengan semakin "menipisnya" batas antara satu negara dengan negara lain. Ketika kelompok yang dominan dapat "melihat" strategi komunikatif yang digunakan oleh lawan tuturnya konyol atau kurang relevan, untuk menciptakan sebuah komunikasi yang efektif, maka ia memerlukan pemahaman terhadap konsep kesantunan yang ada pada kebudayaan lawan tuturnya. Oleh karena itu, untuk meminimalisasi konflik yang terjadi akibat komunikasi lintas budaya, kajian-kajian mengenai prinsip kesantunan dalam berbagai budaya perlu dilakukan, untuk memperluas pemahaman dunia mengenai konsep kesantunan yang ada dalam berbagai kebudayaan yang ada di dunia (Mills, 2011). Terkait dengan hal tersebut, peneliti tertarik untuk melakukan kajian mengenai kesantunan linguistik yang tercermin dalam sebuah kebudayaan, khususnya dalam sebuah ritual religius keagamaan. Adapun objek kajian ini adalah kesantunan linguistik yang tercermin dalam ritual perkawinan dalam agama Hindu yang dianut oleh sebagian besar masyarakat Bali.

Peneliti tertarik untuk mengkaji kesantunan linguistik yang ada dalam ritual pernikahan (pawiwahan) agama Hindu masyarakat Bali disebabkan karena runtutan pernikahan (pawiwahan) agama Hindu masyarakat Bali memiliki struktur yang kompleks, dan melibatkan banyak pihak. Pihak yang dilibatkan tidak hanya berasal dari keluarga kedua mempelai, tetapi juga pemuka adat dan pemuka agama (sulinggih). Proses yang kompleks dan adanya pelibatan banyak pihak memicu munculnya berbagai macam variasi peristiwa komunikasi dengan tingkat kesantunan yang berbeda, sehingga hal ini sangat menarik untuk diteliti.

Beberapa kajian serupa sudah pernah dilaksanakan sebelumnya seperti yang dilakukan oleh Meiliana (2020) yang meneliti mengenai eksistensi tradisi lisan cakap lumat yang digunakan dalam upacara adat perawinan Karo. Demikian pula kajian yang dilakukan Mujahiddin et.al (2019) yang meneliti mengenai bentuk kesantunan berbahasa Bugis bagi masyarakat tutur bahasa Bugis dialek Sinjai di Desa Lere Jaya, Kapupaten Kolaka Timur. Penelitian Halawa (2019) yang mengkaji mengenai kesantunan berbahasa Indonesia dalam tindak tutur melarang dan mengkritik yang dilakukan oleh etnis Minangkabau, Melayu, Mandailing, Jawa, Rejang, Batak dan Nias, dan penelitian Pertiwi (2017) yang mendesripsikan mengenai bentuk kesantunan berbahasa dalam tindak tutur perkawinan tradisioal suku Gayo yang ada di desa Ampakolak. Berbeda dengan beberapa kajian sebelumya (Halawa, Noibe, 2019; Meiliana, 2020; Mujahiddin et.al, 2019; Pertiwi, 2017) yang memfokuskan kajiannya pada bentuk-bentuk kesantunan (pragmatik) yang muncul dalam tradisi lisan, kajian ini selain membahas bentuk kesantunan yang muncul, juga memadukan pendekatan psikolinguistik untuk melihat dampak psikologi yang ingin ditimbulkan pemicara melalui penggunaan bentuk kesantunan yang muncul.

Terkait dengan kajian ini, ada beberapa hal yang akan menjadi fokus adalah aspek vokalik dalam ritual dari segi tempat, waktu, kepada tokoh umat, saat persiapan, pelaksanaan, pengungkapan hubungan dengan Yang Maha Kuasa, dan setelah selesai ritual. Ketiga, perbedanan 
kesantunan linguistik dari segi: tempat, waktu, kepada tokoh umat, saat persiapan, pelaksanaan, pengungkapan hubungan dengan Yang Maha Kuasa, dan setelah selesai ritual. Keempat, faktor yang menyebabkan terjadinya perbedanan kesantunan linguistik dari segi: tempat, waktu, kepada tokoh umat, saat persiapan, pelaksanaan, pengungkapan hubungan dengan Yang Maha Kuasa, dan setelah selesai ritual.

\section{Metode}

Penelitian ini merupakan sebuah studi kualitatif yang dilaksanakan di salah satu pernikahan Hindu Bali yang berlangsung di kota Denpasar dalam kondisi yang natural. Penentuan lokasi penelitian ini menggunakan metode purposive (Edmonds, W \& D. Kennedy, 2017) atas dasar beberapa pertimbangan. Pertama, prosesi ritual upacara pernikahan yang dilakukan lengkap dan sesuai dengan runtutan upacara pernikahan menurut agama Hindu. Kedua, adanya akses peneliti untuk mengobservasi objek penelitian ini pada peristiwa tersebut. Pengambilan data dilaksanakan dengan metode observasi partisipatif tersamar/terselubung dan wawancara (Denzin \& Lincoln, 2018). Data yang diperoleh kemudian dianalisis dengan mengikuti prosedur Miles et.al (2014) yang melibatkan kondensasi data, penyajian data, dan penarikan simpulan. Triangulasi data dilakukan dengan cara triangulasi metode dengan cara observasi, dan wawancara yang didukung oleh dokumentasi berupa rekaman.

\section{Hasil dan Pembahasan}

Hasil penelitian menunjukkan bahwa terdapat kesantunan linguistik dalam ritual pernikahan, dilihat dari segi: tempat, waktu, kepada tokoh umat, saat persiapan, pelaksanan, pengungkapan hubungan dengan yang maha kuasa, dan setelah selesai ritual. Kesantunan linguistik tersebut ditunjukkan dengan adanya penggunaan bahasa Bali dalam tingkatan yang berbeda (level of language) yang disesuaikan dengan tempat, waktu, status sosial, dan kasta mitra tutur. Jika dikaitkan dengan teori kesantunan Brown dan Levinson (1987), penggunaan bahasa Bali yang demikian merupakan sebuah usaha untuk bersikap peduli pada "wajah" atau "muka," baik milik penutur, maupun milik mitra tutur. "Wajah" seseorang akan mengalami ancaman ketika seorang penutur menyatakan sesuatu yang mengandung ancaman terhadap harapan-harapan individu yang berkenaan dengan nama baiknya sendiri, nama baik mitra tutur, dan sebagainya. Oleh karena itu, untuk menunjukkan kesantunan kemudian digunakanlah bahasa Bali dalam tingkatan yang berbeda (level of language) yang disesuaikan dengan tempat, waktu, status sosial, dan kasta mitra tutur.

Penggunaan bahasa Bali dalam tingkatan yang berbeda (level of language) yang disesuaikan dengan tempat, waktu, status sosial, dan kasta mitra tutur untuk menunjukkan kesantunan tersebut juga didasarkan pada pemahaman bahwa dalam budaya Bali, khususnya yang berkaitan dengan penggunaan bahasa, bahasa Bali mengenal beberapa tingkatan bahasa (level of language) yang penggunaanya dapat disesuaikan dengan status mitra tutur. Fakta ini sesuai dengan pandangan (Yule, George, 2017) yang menyatakan bahwa kesantunan merupakan sebuah konsep pasti yang terdapat dalam gagasan perilaku sosial yang santun dalam suatu kebudayaan. Sehingga konsep kesantunan sangat dipengaruhi oleh kebudayaan. Adanya perbedaan bentuk kesantunan sesuai berdasarkan tempat menguatkan hasil kajian Timmer, Christoffels, \& Costa (2019) yang menunjukkan bahwa bentuk-bentuk kebahasaan yang muncul pada seseorang sangat dipengaruh oleh factor-faktor kontekstual yang melingkupinya.

Secara lebih mengkhusus, berikut akan dibahas beberapa temuan menarik dalam penelitian ini berkaitan dengan kesantunan kesantunan linguistik dalam ritual pernikahan, dilihat dari segi: tempat, waktu, kepada tokoh umat, saat persiapan, pelaksanan, pengungkapan hubungan dengan yang maha kuasa, dan setelah selesai ritual. 


\section{Kesantunan Lingustik ketika Berkomunikasi dengan Pemuka Agama}

Kesantunan Linguistik ketika berkomunikasi dengan Pemuka Agama ditunjukkan dengan adanya penggunaan bahasa Bali ragam tinggi (singgih dan sor), dengan nada yang rendah, seperti yang tampak pada kutipan berikut.
APP
Sulinggih
APP
: "Om Swastiastu Ratu”
: "Om Swastiastu sapunapi ning, suwe sampun ten tangkil mriki"
: "Nggih ratu ampura dumun, Sapuniki Ratu, rauh titiang mriki jagi nunas dewasa pawiwahan pianak titiange, malih pidan nika wenten dewasa mesakapan sane becik"
Sulinggih
: "O kenten ning, inggih antos jebos nggih, tiang muspa dumun"
Keterangan
APP
: Ayah dari Pihak Mempelai Pria

Pemuka agama, dalam hal ini sulinggih dipandang memiliki kedudukan utama, sebagai pemimpin agama Hindu. Sulinggih memiliki kedudukan yang mulia dalam tatanan sosial masyarakat Hindu di Bali. Masyarakat Hindu sangat menghormati kedudukan sulinggih karena dipercaya telah mencapai kesucian lahir dan batin. Dinilai suci karena sulinggih telah mengalami upacara madiksa, yang diselenggarakan untuk meningkatkan kesucian diri seseorang. Atas dasar inilah kemudian masyarakat Bali memercayai bahwa sulinggih memiliki tingkat kesucian yang lebih tinggi dibandingkan dengan masyarakat yang lain. Kesucian beliau tersebut, membuat ia dinilai memiliki hubungan yang "dekat" dengan Tuhan (Ida Shang Hyang Widhi Waca). Adanya kepercayaan bahwa sulinggih merupakan orang yang suci inilah yang secara psikologis kemudian mendorong munculnya bentuk-bentuk penghormatan dan penggunaan bahasa ragam tinggi untuk menghormati posisi beliau sebagai orang suci tersebut. Hal ini sesuai dengan pandangan Watts (2005) yang mengemukakan bahwa kepercayaan-kepercayaan tertentu yang ada dalam suatu masyarakat secara psikologis dapat mendorong pemilihan bentuk-bentuk bahasa tertentu yang digunakan ketika berkomunikasi.

Alasan serupa juga tampaknya menjadi penyebab psikologis penggunaan bahasa Bali ragam tinggi (singgih dan sor), dengan nada yang rendah pada welaka, dan wang jero yang "melayani" sulinggih. Meskipun jika dilihat dari segi kasta mereka (welaka dan wang jero) memiliki kasta yang lebih rendah dibandingkan dengan keluarga mempelai laki-laki. Walaupun tidak melalui prosesi madiksa, tingkat intensitas interaksi mereka dengan orang suci (sulinggih) yang tinggi serta dibarengi dengan tingginya frekuensi keterlibatan dalam upacara keagaamaan, membuat mereka juga dipandang memiliki tingkat kesucian yang lebih tinggi dibandingkan dengan masyarakat biasa. Hal inilah yang kemudian memicu penggunaan bahasa Bali ragam tinggi (singgih dan sor), dengan nada yang rendah. Berikut disajikan salah satu kutipan yang menunjukkan hal tersebut.

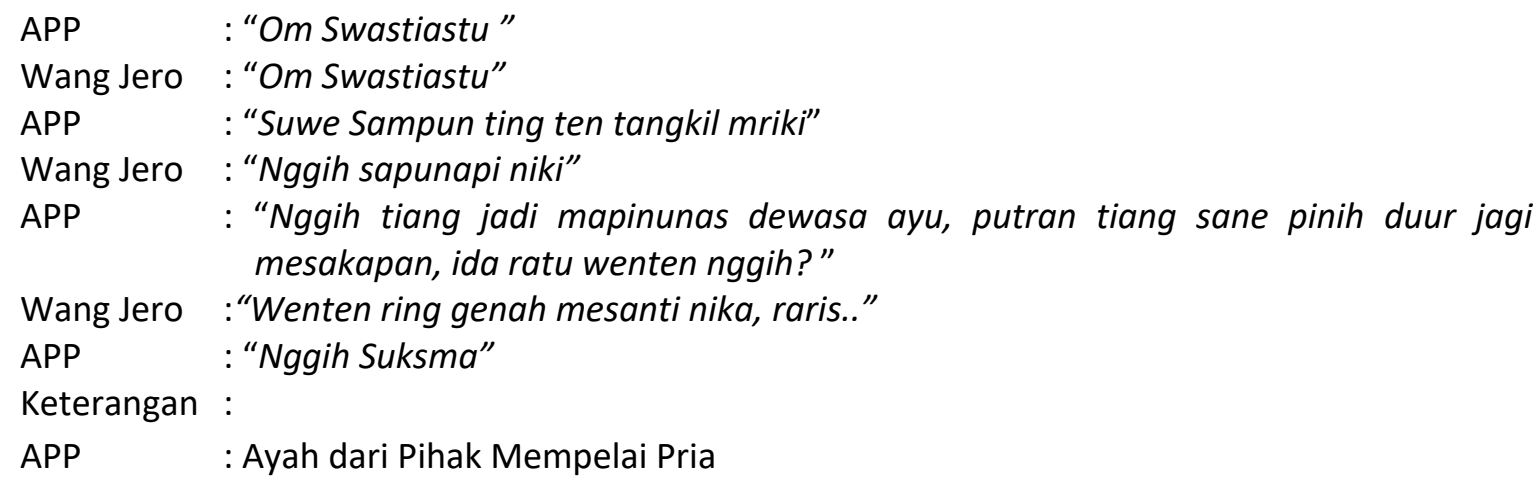


Bila dikaitkan dengan teori kesantunan Leech (1991) pemilihan penggunaan bahasa Bali ragam tinggi (singgih dan sor) tersebut sesuai dengan maksim penghargaan, yang menjelaskan bahwa seseorang akan dapat dianggap santun apabila dalam bertutur selalu berusaha memberikan penghargaan kepada pihak lain. Dalam penelitian ini, ditemukan bahwa penghargaan tersebut diberikan dengan menggunakan bahasa Bali ragam tinggi (singgih dan sor). Bentuk penghargaan juga terlihat dari penggunaan kata-kata honorifik, yaitu ungkapan hormat untuk berbicara dan menyapa orang lain, seperti menyebut sulinggih dengan "Ratu".

\section{Kesantunan Linguistik ketika Prosesi Memadik}

Pada prosesi memadik ini keluarga besar dari pihak calon pengantin pria datang ke rumah calon pengatin wanita untuk meminang. Pada saat melamar, keluarga mempelai laki-laki mengutarakan maksud kedatangannya ke kediaman calon pengantin wanita. Dalam mengutarakan maksudnya tersebut, keluarga mempelai laki-laki menunjuk satu orang perwakilan sebagai seorang juru raos, yang bertugas sebagai perpanjangan tangan pihak calon pengantin pria untuk berkomunikasi dengan pihak mempelai wanita. Hal yang sama juga terjadi pada pihak calon pengantin wanita. Pihak pengantin wanita juga menunjuk satu orang perwakilan sebagai seorang juru raos. Pihak yang ditunjuk sebagai juru raos dari pihak laki-laki adalah ayah mempelai pria, sedangkan juru raos dari pihak wanita adalah paman calon mempelai wanita.

Secara keseluruhan pilihan bahasa yang digunakan dalam prosesi memadik, baik oleh pihak keluarga calon mempelai laki-laki dan wanita menggunakan ragam bahasa Bali singgih dan sor. Hal ini dimaksudkan untuk menghormati keluarga mempelai yang telah berkenan hadir salam acara tersebut. Aspek vokalik yang ditunjukkan terkait dengan penggunaan nada dan intonasi juga cenderung rendah. Secara lebih khusus berikut diuraikan bentuk kesantunan berbahasa yang terjadi dalam prosesi upacara memadik.

Salah satu gambaran kesantunan linguistik yang paling jelas tampak pada penelitian ini adalah pada saat prosesi upacara memadik. Kesantunan linguistik tersebut diwujudkan dalam tindak tutur bersalaman, memaparkan silsilah keluarga, dan meminta. Dimana penyampainnya didominasi oleh ragam bahasa Bali singgih dan sor, yang dilakukan untuk menghormati keluarga pihak wanita.

Pada tindak tutur bersalaman, kedua belah keluarga mengawali pembicaraan dengan mengucapkan salam "Om Swastiastu", seperti yang tampak pada kutipan berikut.

APP : "Om Swastyastu,...Inggih pengeraos titing mriki sareng keluarga nenten wenten tios wantah jagi nunas putri dane jagi kejatuh karmaang sareng pianak titiang"

Keterangan:

APP : Ayah Pihak Mempelai Pria

Secara psikologi, terdapat beberapa penyebab digunakannya salam ini. Pertama, dalam ajaran Agama Hindu, terdapat kepercayaan bahwa ketika bertemu dengan sesama maka hendaknya menyapa dengan mengucapkan "Om Swastiastu". Kedua, adanya kepercayaan bahwa "Om Swastiastu" bukan sekadar salam biasa, di dalamnya juga terkandung doa, agar selamat dan selalu berada atas rahmat Tuhan Yang Maha Esa. Ketiga, adanya kepercayaan bahwa dengan diucapkannya salam ini secara tidak langsung menyatakan niat untuk membina hubungan yang harmonis dan mempererat rasa persaudaraan dalam pergaulan. Sehingga dengan diucapkannya salam ini, maka secara psikologis, keluarga mempelai wanita akan dapat memahami itikad baik dari keluarga mempelai pria untuk memulai pembicaraan untuk membina sebuah hubungan keluarga.

Pada tindak tutur memaparkan silsilah keluarga, masing-masing pihak keluarga tidak secara langsung menunjukkan anggota keluarga. Sebelum mereka mengemukakan posisi seseorang dalam silsilah keluarga mereka memberikan semacam "pengantar" terlebih dahulu. Hal ini dilakukan untuk menunjukkan sikap santun dan penghormatan kepada orang-orang yang menempati posisi tertentu dalam sebuah silsilah keluarga. Jika dilihat dari prinsip kesantunan 
Leech (1991) hal ini sesuai penerapan maksim kebijaksanaan, yang menyatakan bahwa semakin panjang tuturan seseorang, semakin besar pula keinginan orang itu untuk bersikap santun kepada lawan bicaranya.

Pada tindak tutur meminta, kata "nunas" memiliki frekuensi kemunculan yang tinggi. Kata "nunas" secara harfiah memiliki kesan makna yang lebih halus daripada jika seseorang menggunakan kata "tunas". Atau dengan kata lain, tingkat permohonannya lebih tinggi/ lebih dalam. Dengan menggunakan kata "nunas", seseorang memposisikan diri jauh lebih "rendah" dari orang tempat ia meminta atau dalam arti memberikan penghormatan tinggi kepada orang tempat ia meminta.

APP : "Anak alit titiang kocap tresna ring anak alit isteri iriki, anak alit isteri iriki kocap tresna ring anak alit titiang. Wentene tresna ketresnain punika anak alit titiang memanah pacang nincapang ke grehasta asrama. Punika mawinan titiang nangkilin pengelingsir iriki mapisarat nunas pikayun pengelingsire iriki ledang ngicenin panugrahan utawi pamargi sane antar mangdane anake alit makekalih praside matemu alaki rabi. Inggih, titiang ngelungsur pikayunan pengelingsir mangda ledang ugi nagingin pinunas titiang matemuang anake alit makekalih."

Keterangan:

APP : Ayah Pihak Mempelai Pria

Dengan adanya penggunaan kata nunas ini diharapkan mampu menimbulkan dampak psikologis kepada pihak keluarga mempelai wanita. Dampak psikologis yang dimaksud adalah kerelaan untuk melakukan sesuatu yang diminta dalam tindak tutur yang disampaikan. Misalnya, kerelaan untuk memanggil mempelai wanita keluar dari rumah, dan kerelaan untuk menerima pinangan mempelalai pria.

\section{Kesantunan Linguistik Pada saat Menerima Tamu}

Bentuk kesantunan linguistik juga peneliti dapat observasi pada saat penerimaan tamu, baik pada saat persiapan ritual, pelaksanaan, maupun setelah ritual usai. Kesantunan linguistik tersebut tampak pada saat pihak keluarga mempelai pria menyampaikan sambutan maupun mengakhiri prosesi sebuah acara. Bentuk kesantunan linguistik terlihat dari adanya penggunana kata-kata yang menunjukkan rasa terima kasih kepada hadirin yang telah bersedia hadir. Seperti penggunaan kalimat "... titiang ngaturang suksmaning manah ping banget.." dan bentuk-bentuk penghormatan seperti "sane dahat suciang titiang", "sane dahat wangiang titiang", "sane dahat katresna asihin titiang". Kesantunan linguistik juga tampak dari aspek vokalik, yang berkaitan dengan nada dan intonasi yang digunakan. Pengucapan kata "titiang" diucapkan dengan intonasi dan nada yang rendah. Hal ini dilakukan dengan maksud untuk "meninggikan" tamu-tamu yang telah bersedia hadir.

Keluarga mempelai laki-laki, yang dalam hal ini berasal dari kasta Brahmana dilihat dari pilihan kata yang digunakan rela "merendahkan" dirinya dihadapan hadirin yang tidak hanya berasal dari kasta Brahmana, tetapi juga kasta lain yang berada di bawah kasta Brahmana. Hal ini dengan sengaja dilakukan agar pihak tamu merasa dihormati dan dihargai. Dengan munculnya perasaan dihormati dan dihargai ini, secara tidak langsung akan timbul kerelaan di dalam diri tamu/warga yang datang untuk membantu penyelenggaraan prosesi upacara pernikahan. Jika dikaitkan dengan teori kesantunan Leech (1991) maka hal yang dilakukan oleh pihak mempelai laki-laki tersebut sesuai dengan maksim penghargaan. Dalam maksim penghargaan dijelaskan bahwa seseorang akan dapat dianggap santun apabila ia sebisa mungkin "meninggikan" lawan tuturnya dengan "merendahkan" diri sendiri. 


\section{Kesantunan Linguistik Pada saat Berkomunikasi dengan Pemuka Adat}

Kesantunan linguistik saat berkomunikasi dengan kelian adat tampak pada saat keluarga mempelai pria datang untuk meminta kesediaan kelian adat untuk ikut serta mendampingi prosesi memadik sekaligus menjadi saksi pada saat prosesi upacara pernikahan berlangsung. Berdasarkan hasil observasi tampak bahwa pihak keluarga laki-laki dalam berkomunikasi menggunakan pilihan ragam bahasa Bali singgih dan mider dengan pilihan nada yang rendah, yang dimaksudkan untuk memberikan penghargaan dan penghormatan kepada kelian adat. Hal tersebut tampak pada pengunaan pilihan kata "mapinunas" dan "mangda sida". Meskipun, jika dilihat dari segi kasta, kelian adat memiliki kasta yang lebih rendah (ksatria), pihak keluarga mempelai laki-laki tetap menggunakan bahasa Bali singgih dan mider untuk memberikan penghargaan terhadap status sosial kemasyarakatan yang dimiliki oleh kelian adat. Bila dikaitkan dengan teori kesantunan Leech (1991) hal yang dilakukan oleh pihak keluarga mempelai pria juga merupakan penerapan maksim penghargaan yang menyatakan bahwa seseorang akan dapat dianggap santun apabila dalam bertutur selalu berusaha memberikan penghargaan kepada pihak lain.

\section{Kesantunan Linguistik Pada saat Pengungkapan Hubungan dengan Tuhan}

Kesantunan Linguistik saat pengungkapan hubungan dengan Tuhan Yang Maha Kuasa ditunjukkan dengan penggunaan bahasa Bali ragam tinggi (alus singgih) dan mantra. Ragam bahasa Bali singgih digunakan untuk mengucapkan permohonan tertentu sedangkan mantra digunakan untuk menyampaikan doa dan menghatarkan pelaksanan ritual pernikahan oleh sulinggih.

Penggunaan bahasa Bali ragam tinggi (alus singgih) ketika mengucapkan permohoanan tertentu kepada Tuhan (Ida Shang Hyang Widhi) tersebut didasarkan atas kepercayaan bahwa Tuhan adalah penguasa alam semesta dan entitas paling suci menurut suatu kepercayaan. Oleh karena itu, maka kemudian digunakanlah bentuk kebahasaan yang paling baik dan paling tinggi untuk berkomunikasi dengan-Nya. Dalam kajian ini bentuk kebahasaan paling tinggi dalam budaya Bali adalah bahasa Bali alus singgih.

Terkait dengan doa-doa yang digunakan dalam ritual prosesi upacara pernikahan, baik yang dipanjatkan oleh kedua mempelai maupun yang digunakan oleh sulinggih untuk menghantarkan upacara seluruhnya menggunakan bahasa sansekerta yang diambil dari Weda yang merupakan suci dalam agama Hindu. Adanya penggunaan sloka-sloka yang bersumber dari kitab suci tersebut didasarkan pada adanya kepercayaan bahwa kitab suci Weda wahyu yang diturunkan oleh Hyang Widhi melalui para Rsi, yang kemudian dikumpulkan atau dihimpun menjadi suatu kitab suci. Sehingga, dengan menggunakan sloka-sloka yang terdapat dalam Weda tersebut manusia dapat berkomunikasi dengan Tuhan (Ida Sang Widhi).

Dalam kegiatan persembahyangan, seorang umat melakukan komunikasi dengan Tuhan atau leluhur melalui perantara bahasa (mantra). Melalui perantara bahasa tersebut seorang umat merasa seolah-olah berkomunikasi dengan Tuhan atau leluhur. Suasana religius yang demikian, dapat menolong orang untuk mengungkapkan segala perasaan, keluh kesah, dan berpasrah diri (Savelyuk \& Tkach, 2019). Melalui suasana yang demikian, seorang umat akan memperoleh ketenangan jiwa karena merasa dekat dengan Tuhan atau leluhur dan merasa dibimbing serta diberikan petunjuk oleh-Nya. Berbekal ketenangan jiwa yang diperoleh melalui kegiatan persembahyangan inilah kemudian umat dapat melaksanakan seluruh prosesi upacara pernikahan dengan baik dan penuh suka cita (Fincham \& May, 2020).

Berkaitan dengan perbedaan kesantunan linguistik dari segi: tempat, waktu, kepada tokoh umat, saat persiapan, pelaksanaan, pengungkapan hubungan dengan yang maha kuasa, dan setelah selesai ritual, Hasil penelitian menunjukkan bahwa tidak terdapat perbedaan yang signifikan dalam hal cara pengungkapan kesantunan linguistik. Jika mitra tutur memiliki status sosial yang lebih tinggi, seperti kelian adat atau sulinggih, maka bentuk bahasa yang digunakan adalah bahasa Bali ragam tinggi dengan intonasi dan nada rendah. Hal ini berlaku dimanapun, baik ketika berada di griya maupun di 
luar griya. Jika mitra tutur berasal dari kasta yang sama (Brahmana) maka bentuk kebahasaan yang digunakan adalah ragam bahasa Bali alus singgih dan sor. Jika mitra tutur berasal dari kasta yang lebih rendah dari penutur, maka penutur akan menggunakan ragam bahasa Bali Madya/Mider untuk situasi yang bersifat personal. Jika dalam situasi resmi, misalnya saat memberikan sambutan, meskipun mitra tutur berasal dari kasta yang lebih rendah dari penutur, untuk menghormati mitra tutur, penutur menggunakan bahasa Bali alus singgih dan sor. Jika berkomunikasi atau menyatakan hubungan dengan Tuhan maka bentuk kebahasaan yang digunakan adalah ragam bahasa Bali singgih atau bahasa sansekerta (bahasa doa), baik yang dilakukan di dalam pamerajan maupun di luar pamerajan.

Berdasarkan gambaran mengenai perbedaan kesantunan linguistik dari segi: tempat, waktu, kepada tokoh umat, saat persiapan, pelaksanaan, pengungkapan hubungan dengan yang maha kuasa, dan setelah selesai ritual yang tergambar pada bagian sebelumnya, dapat disimpulkan bahwa perbedaan yang terjadi disebabkan oleh dua hal. Pertama, jarak sosial penutur dan mitra tutur. Adanya perbedaan penggunaan bahasa yang digunakan oleh keluarga mempelai ketika berkomunikasi dengan pemuka adat dan agama dengan bahasa bahasa yang digunakan ketika berkomunikasi dengan warga yang memiliki kedekatan hubungan merupakan suatu fakta kesantunan bersifat relatif bergantung dari mitra tutur yang dihadapi. Fakta lain ditunjukkan dengan digunakannya bahasa Bali ragam tinggi oleh orang yang memiliki kasta rendah (kelian adat dan warga yang berkasta sudra) kepada orang yang berkasta Brahmana. Fakta demikian sesuai dengan pandangan Thomas (1995) yang menyatakan bahwa bersikap atau berbahasa santun dan beretika juga bersifat relatif, tergantung pada jarak sosial penutur dan mitra tutur.

Kedua, situasi yang melingkupi peristiwa tutur. Adanya perbedaan penggunaan bahasa yang digunakan oleh keluarga mempelai ketika berkomunikasi dengan warga yang memiliki kasta lebih rendah ketika situasi personal dan resmi merupakan salah satu fakta yang menunjukkan hal ini. Ketika situasi bersifat personal, penutur menggunakan bahasa Bali madya/mider, sedangkan ketika berada dalam situasi resmi untuk menunjukkan penghargaan yang lebih digunakan ragam bahasa Bali alus singgih dan sor. Hal ini sesuai dengan pandangan Yule (2017) yang menyatakan bahwa salah satu faktor yang mempengaruhi pilihan bahasa untuk menunjukkan kesantunan adalah situasi yang melingkupi suatu peristiwa tutur.

\section{Simpulan}

Berdasarkan data hasil observasi ditemukan bentuk kesantunan linguistik dalam ritual pernikahan agama Hindu di Bali dilihat dari segi tempat, waktu, kepada tokoh umat, saat persiapan, pelaksanaan, pengungkapan hubungan dengan Yang Maha Kuasa, dan setelah selesai ritual. Kesantunan linguistik tersebut dapat dilihat dari penggunaan bahasa Bali dalam berbagai tingkatan yang disesuaikan dengan jarak sosial dan situasi tuturan. Selain terlihat dari penggunaan bahasa, kesantunan linguistik juga tampak dari sikap, intonasi, dan nada penutur.

Perbedaan kesantunan linguistik dari segi: tempat, waktu, kepada tokoh umat, saat persiapan, pelaksanaan, pengungkapan hubungan dengan Yang Maha Kuasa, dan setelah selesai ritual terletak pada pilihan bahasa yang digunakan untuk berkomunikasi dan pengunaan prosodi (nada dan intonasi). Perbedaan kesantunan linguistik dari segi: tempat, waktu, kepada tokoh umat, saat persiapan, pelaksanaan, pengungkapan hubungan dengan Yang Maha Kuasa, dan setelah selesai ritual disebabkan karena dua hal, yaitu (1) jarak sosial penutur dan mitra tutur; (2) situasi yang melingkupi peristiwa tutur.

Melalui hasil penelitian sederhana ini, mahasiswa mendapatkan gambaran awal mengenai kesantunan linguistik dalam ritual, khususnya ritual pernikahan agama Hindu yang ada di Bali. Peneliti lain diharapkan melalukan penelitian sejenis agar mendapat gambaran yang komprehensif mengenai kesantunan linguistik dalam ritual, khsususnya dalam ritual pernikahan agama Hindu yang ada di Bali. 


\section{Daftar Pustaka}

Denzin, N. K., \& Lincoln, Y. S. (2018). The SAGE Handbook of Qualitative Research. Fifth Edition. In SAGE Publication. https://doi.org/10.1007/s11229-017-1319-x

Edmonds, W, A., \& D. Kennedy, T. (2017). An Applied Guide to Research Designs Quantitative, Qualitative, and Mixed Methods Second Edition - W. Alex Edmonds Thomas D. Kennedy Nova Southeastern University. • 1): ISAGE LOS Angeles I London I New Delhi Singapore I.

Fincham, F. D., \& May, R. W. (2020). Generalized gratitude and prayers of gratitude in marriage. Journal of Positive Psychology, 00(00), 1-6. https://doi.org/10.1080/17439760.2020.1716053

Halawa, Noibe, E. a. (2019). Kesantunan Berbahasa Indonesia Dalam Tindak Tutur Melarang Dan Mengkritik Pada Tujuh Etni. Lingua, 15(2), 195-205.

Isosävi, J. (2020). Cultural outsiders' reported adherence to Finnish and French politeness norms. Journal of Pragmatics, 155, 177-192. https://doi.org/10.1016/j.pragma.2019.10.015

Lakoff, R. T. and S. I. (2005). Broadening the horizon of linguistic politeness. In WORD. Amsterdam: John Benjamins Publishing Company.

Meiliana, S. (2020). Eksistensi Tradisi isan Cakap Lumat dalam Upacara Adat Perkawinan Karo. LITERA, 19(1), 157-172.

Miles, Matthew B., A. Michael HUberman, and J. S. (2014). Qualitative Data Analysis: a Methods Sourcebook (Third edit). California: Sage Publication.

Mills, S. and D. Z. K. (2011). Politeness and Culture. In D. and S. M. Kadar (Ed.), Politeness in East Asia (pp. 21-44). https://doi.org/10.1515/9783110214338.1.71

Mujahiddin et.al. (2019). Kesantunan Berbahasa Bugis bagi Masyarakat Tutur Bahasa Bugis Dialeg Sinjai di Desa Lere Jaya Kabupaten Kolaka Timur. Jurnal Pendidikan Bahasa, 8(2), 84-92. Retrieved from http://ojs.uho.ac.id/index.php/JPB

Nurilaila, E., \& Madiun, U. P. (2020). National Cultures and Politeness Strategies in Intercultural Communication Among Japanese and American C haracters in "The Last $\mathrm{S}$ amurai" Movie : A Cross-Cultural Pragmatic Analysis. Social Sciences, Humanities and Education Journal (SHE Journal), 1(January), 10-17. Retrieved from http://ejournal.unipma.ac.id/index.php/SHE\%OANational

Pertiwi, D. (2017). KESANTUNAN BERBAHASA DALAM TINDAK TUTUR PERKAWINAN SUKU GAYO DI DESA AMPAKOLAK KECAMATAN RIKIT GAIB KABUPATEN GAYO LUES. Journal of Chemical Information and Modeling, 2(1), 1-13.

Savelyuk, N., \& Tkach, T. (2019). Psycholinguistic peculiarities of non-canonical (personal) religious discourse. Psiholingvistika, 26(1), 286-305. https://doi.org/10.31470/2309-1797-2019-26-1286-305

Spencer-oatey, H., \& Kádár, D. (2016). The bases of ( im ) politeness evaluations : Culture, the moral order and the East - West debate. East Asian Pragmatics, 1(1), 73-106. https://doi.org/10.1558/eap.v1i1.29084

Timmer, K., Christoffels, I. K., \& Costa, A. (2019). On the flexibility of bilingual language control: The effect of language context. Bilingualism, 22(3), 555-568.

https://doi.org/10.1017/S1366728918000329

Yule, George, 1947-. (2017). The Study of language (Sixth Edit). United Kingdom: Cambridge University Press. 